\title{
CARACTERÍSTICAS DO FINANCIAMENTO DO CAPITAL DE GIRO DE PEQUENAS EMPRESAS DO SUL DE SANTA CATARINA
}

\section{CHARACTERISTICS OF THE FINANCING OF THE SHARE CAPITAL OF SMALL COMPANIES FROM THE SOUTH OF SANTA CATARINA}

\author{
Recebido: 16/10/2017 - Aprovado: 20/11/2017 - Publicado: 30/12/2017
} Processo de Avaliação: Double Blind Review

\author{
Rodney Wernke ${ }^{1}$ \\ Doutor em Engenharia de Produção \\ Professor da Universidade do Sul de Santa Catarina (Unisul) \\ Professor da Universidade Comunitária da Região de Chapecó (Unochapecó) \\ rodney.wernke@unisul.br \\ Aline Luiza Brusco Pletsch \\ Mestranda no PPGCCA/Unochapecó \\ Universidade Comunitária da Região de Chapecó (Unochapecó) \\ aline.brusco@live.com \\ Ivone Junges \\ Universidade do Sul de Santa Catarina (Unisul) \\ Doutora em Engenharia de Produção/UFSC. \\ Professora no Curso de Administração da UNISUL. \\ ivone.junges@unisul.br \\ Antonio Zanin \\ Doutor em Engenharia de Produção/UFRGS \\ Universidade Comunitária da Região de Chapecó (Unochapecó) \\ zanin@unochapeco.edu.b
}

RESUMO: O objetivo do estudo foi identificar as principais características da captação de recursos para capital de giro das pequenas empresas da microrregião da Amurel (sul de Santa Catarina). Para tanto, realizou-se levantamento de dados por meio de sondagem (survey) com abordagem quantitativa. A amostra da pesquisa foi composta por 299 empresas de pequeno porte sediadas na área citada e a aplicação do questionário ocorreu nos meses de abril a junho de 2016. Após uma breve revisão da literatura foram abordados os procedimentos metodológicos adotados, descritas as principais características das entidades abrangidas e apresentados os resultados da pesquisa. A principal contribuição teórica do estudo reside na evidenciação das peculiaridades relacionadas às práticas de financiamento do capital de giro no âmbito das pequenas empresas. Nesse sentido, restou evidenciado que há uma intenção de evitar

\footnotetext{
${ }^{1}$ Autor para correspondência: Unochapecó, Avenida Senador Attílio Fontana, 591-E - Efapi, Chapecó - SC, Brasil, 89809-000.
}

REMIPE- Revista de Micro e Pequenas Empresas e Empreendedorismo da Fatec Osasco 
o crédito bancário, mas quando recorrem a essa forma de captação priorizam os bancos comerciais em detrimento de agências de fomento ou cooperativas de crédito e preferem taxas de juros mensais inferiores a $2 \%$. Os motivos mais alegados para justificar a fuga das operações de crédito são as altas taxas de juros, a instabilidade econômica do país e a incerteza quanto ao futuro da empresa. Ainda, no caso de insuficiência de dinheiro para quitar as dívidas, a primeira iniciativa é na direção de negociar com fornecedores para postergar os prazos de pagamento.

Palavras-chave: captação de recursos; capital de giro; levantamento.

ABSTRACT: the objective of the study was to identify the main characteristics of the funding of working capital of small enterprises in the Amurel microregion (south of Santa Catarina). For that, a data ballot was carried out by means of a survey with a quantitative approach. The poll sample consisted of 299 small firms based on the mentioned field and the application of the questionnaire occurred in the months from April to June 2016. After a brief review of the literature, the methodological procedures adopted were described, revealing the main characteristics of the companies and the results of the survey. The main theoretical contribution of the study lies in the evidence of the peculiarities related to working capital financing practices in small enterprises. In this sense, it was evidenced that there is an intention to avoid bank credit, but when they use this form of funding they prioritize commercial banks to the detriment of development agencies or credit unions and prefer monthly interest rates of less than $2 \%$. The most alleged reasons to justify the escape of credit operations are the high interest rates, the economic instability of the country and the uncertainty about the future of the company. Still, in the case of insufficient money to pay off debts, the first initiative is in the direction to negotiate with suppliers to postpone payment deadlines.

Keywords: fundraising; working capital; survey.

\section{INTRODUÇÃO}

Os gestores se deparam constantemente com decisões acerca do financiamento dos projetos e das atividades operacionais das empresas, envolvendo principalmente taxas de juros, prazos e fontes de captação (capital próprio ou alheio). Nesse rumo, Costa, Costa e Alvim (2011, p. 25) asseveram que "os investimentos precisam ser financiados da forma mais 
equilibrada possível entre recursos próprios (aporte de sócios e lucros retidos) e recursos de terceiros".

Sobre o equacionamento das possíveis origens dos recursos, uma das pesquisas mais relevantes sobre a decisão da melhor estrutura de capital foi apresentada por Modigliani e Miller (1958), que concluíram que a estrutura de capital é irrelevante. Canongia (2014) registra que a partir de então têm sido desenvolvidas pesquisas e teorias que objetivam explicar o endividamento das empresas a partir do relaxamento dessas premissas, o que fez surgir várias teorias sob enfoques diversificados. Acerca disso, estudo apresentado por Durand (1952) coloca os benefícios fiscais como determinantes do endividamento, evidenciando o pressuposto do nível de endividamento limitado. Contudo, Modigliani e Miller (1963, p. 442) aduzem que "a existência de benefícios fiscais para o endividamento não necessariamente significa que as empresas devam buscar, a todo momento, usar a quantidade máxima possível de dívida em suas estruturas de capital". Nessa direção, afirmam que algumas empresas podem ter "necessidade de preservar a flexibilidade", o que "normalmente implica a manutenção pela corporação de uma reserva substancial de poder de endividamento inexplorado".

O investimento que as empresas almejam a curto prazo é a acumulação de capital físico, que é viabilizado pela obtenção de crédito junto ao setor financeiro. Entretanto, isso varia de forma positiva em relação à taxa de lucro e de forma negativa à taxa de juros e, em concordância com o resultado correspondente, da diferença entre o grau de endividamento efetivo e o desejado como máximo pelas empresas (Lima \& Meirelles, 2005).

É importante que o gestor financeiro saiba apurar os custos de seus financiamentos (tanto de curto como de longo prazo) e que tenha também conhecimento profundo sobre os instrumentos de captação de financiamentos. Para tanto, além do volume de recursos necessários, a decisão de financiamento exige conhecer as alternativas de crédito disponíveis no mercado, a análise de seus custos e riscos respectivos, bem como as garantias exigidas (Assaf Neto \& Lima, 2010).

Nesse sentido, as decisões sobre a viabilidade de investimentos não devem ser tomadas sem que antes sejam averiguados os custos dos financiamentos necessários para suportá-los, devendo ser apurados a partir das alternativas entre endividamento e capital próprio (Perobelli e Famá, 2003).

Por sua vez, Nakamura, Jucá e Bastos (2011) informam que existem vários determinantes da estrutura e da maturidade da dívida, citando como exemplos o nível de crescimento e o tamanho da empresa, o grau de alavancagem, a variação dos montantes da REMIPE- Revista de Micro e Pequenas Empresas e Empreendedorismo da Fatec Osasco 
dívida, o momento de emissão das dívidas e a forma que ocorre a participação dos administradores no capital da empresa. Contudo, referidos autores mencionam que a partir dos estudos referentes ao endividamento das empresas e o progresso apurado nessas pesquisas, visualiza-se que o cenário brasileiro pode ser considerado como um campo amplo e pouco explorado para entendimento desse processo.

A partir desse contexto questiona-se: quais são as principais características da captação de recursos para capital de giro das pequenas empresas da microrregião da Amurel (sul de Santa Catarina)? O objetivo do estudo é identificar as peculiaridades relacionadas à captação de recursos para giro nesse porte de empresas na área geográfica mencionada.

Estudos com esse foco se justificam por, ao menos, dois aspectos: pela relevância econômica das pequenas empresas e pela necessidade de se conhecer as práticas adotadas por estas no que concerne à captação de recursos para o capital de giro. Quanto ao aspecto econômico, várias pesquisas destacaram a importância das pequenas empresas para a economia de diversos países, principalmente na geração de empregos e renda (Van Stel, Carre, \& Thurik, 2005; Audretsch \& Beckmann, 2007). Porém, há entraves que comprometem a competitividade destas e acarretam o encerramento de suas atividades. Estudo divulgado pelo Sebrae-SC (2013) aponta que a cada 100 empresas criadas em Santa Catarina somente 76, em média, sobrevivem aos dois primeiros anos de vida. No município de Tubarão (maior cidade da microrregião onde foi realizada esta pesquisa) esse índice foi de 77\%, em Criciúma de 68\% e em Florianópolis de $70 \%$, enquanto que a média nacional foi de 75,6\%. No mesmo rumo, Vogel e Wood Jr. (2012) mencionam outra pesquisa sobre mortalidade empresarial, realizada pelo Sebrae-SP em 2009, que revelou que $27 \%$ das empresas constituídas no estado de São Paulo são encerradas em seu primeiro ano de existência e somente $42 \%$ das empresas constituídas sobrevivem após o quinto ano de existência.

Provavelmente uma parte dessas dificuldades está atrelada à captação de recursos para financiar as operações mercantis, especialmente em relação ao capital de giro necessário para suportar as atividades comerciais de aquisição de insumos/mercadorias, estocagem e financiamento das vendas (Carvalho \& Abramovay, 2004). No mesmo rumo, Cassiolato, Britto e Vargas (2002) asseveram que o acesso limitado aos mercados de crédito dificulta o fortalecimento e a sobrevivência de empresas de menor porte. Como essa realidade provavelmente também se faz presente na microrregião da Amurel, pretende-se contribuir com a ampliação dos conhecimentos sobre esse contexto por intermédio de um diagnóstico acerca do tema em lume no âmbito da região citada. Com isso, se almeja também proporcionar REMIPE- Revista de Micro e Pequenas Empresas e Empreendedorismo da Fatec Osasco 
informações úteis para associações comerciais, órgãos governamentais de crédito, profissionais da gestão financeira e das instituições universitárias da microrregião mencionada acerca dos fatores que inibem ou estimulam a captação de recursos para o capital de giro das empresas pesquisadas.

\section{REVISÃO DA LITERATURA}

As próximas seções evidenciam os conceitos mais diretamente atrelados ao foco desta pesquisa, que serviram como base para o instrumento de pesquisa utilizado, bem como para a análise dos resultados provenientes.

\subsection{CAPITAL DE GIRO}

Entre as possibilidades de aplicação de recursos em ativos, uma grande parcela tende a ser destinada aos ativos correntes (ou circulantes), sendo que esses ativos compreendem os saldos mantidos por uma empresa em disponibilidades, investimentos temporários, contas a receber e estoques de matérias-primas, mercadorias para venda, produção em andamento e produtos acabados (Sanvicente, 2010).

Dorabelia (1995) menciona que a expressão capital de giro designa os recursos financeiros aplicados pela empresa na execução do ciclo operacional de seus produtos, sendo que esses recursos serão recuperados financeiramente ao final deste ciclo. Nesse sentido, Fleuriet, Kehdy e Blanc (2003) defendem que o capital de giro é um conceito econômicofinanceiro e não uma definição legal, configurando-se como uma fonte de fundos permanentemente utilizada para financiar a necessidade de capital para as operações mercantis da empresa.

A gestão do capital de giro caracteriza-se por ser muito dinâmica, o que necessita a atenção diária dos gestores financeiros. Falhas nesta área de atuação podem comprometer a capacidade de solvência da empresa ou prejudicar a sua rentabilidade (Braga, 1991). Nessa direção, dados de pesquisa do SEBRAE (2004) evidenciam que a principal causa para o fechamento de empresas é a falta de capital de giro e que este representa, em média, um terço do investimento total a ser realizado pelos empreendedores.

Acerca disso, Rochman (2007) salienta que muitas vezes esse fenômeno da morte precoce de empresas acontece pela ausência de planejamento e de uma estimativa correta do total de investimento necessário no capital de giro da empresa, o que acontece pela falta de conhecimento a respeito da gestão desse aspecto. Por outro lado, o excesso de capital de giro REMIPE- Revista de Micro e Pequenas Empresas e Empreendedorismo da Fatec Osasco 
também pode se tornar prejudicial. Rochman (2007) aduz que a existência de capital de giro em demasia pode comprometer a rentabilidade da empresa, pois alguns dos ativos que integramno geram baixos retornos, prejudicando a criação de valor das companhias. Destarte, pode ser visto como um "mal necessário", pois ao mesmo tempo que pode proporcionar baixo retorno, tende a ser essencial para a sobrevivência do empreendimento.

Nesse contexto a definição de um posicionamento ideal na administração de capital de giro é um grande desafio para os gestores financeiros. Gitman (1997) considera que um dos itens de maior relevância em relação aos itens circulantes é definir como usar os passivos circulantes para financiar os ativos circulantes, de vez que o valor do passivo circulante é determinado pelo valor das compras a prazo, pelo valor das despesas e o valor dos empréstimos. Belt (1979) registra que o investimento real em capital de giro é a liquidez dos ativos circulantes e a forma como a empresa posterga o pagamento de suas obrigações correntes, sendo a capacidade do administrador de prever suas vendas futuras um fator determinante de liquidez dos ativos.

Por sua vez, Fleuriet, Kehdy e Blanc (2003) acrescentaram ao conceito clássico de Capital de Giro Líquido (CGL) os conceitos de Necessidade de Capital de Giro (NCG) e Saldo de Tesouraria (T). Para que chegassem nesse resultado, efetuaram a reclassificação das contas do ativo e passivo de acordo com a realidade dinâmica das empresas, classificando as contas de acordo com seu ciclo. Nesse âmbito, quando analisadas de forma isolada ou relacionadas ao grupo de outras contas, determinadas contas mostram movimentação tão lenta que, analisando no curto prazo, permitem ser consideradas como "permanentes" ou não "cíclicas". Do mesmo modo, outras contas se relacionam com o ciclo operacional da empresa e mostram um movimento contínuo e cíclico (Machado, Machado \& Callado, 2006).

Portanto, verifica-se que a gestão do capital de giro objetiva administrar cada conta pertencente ao ativo e passivo circulantes, de tal forma que mantenha, conforme a visão da empresa em termos de liquidez e rentabilidade, um valor mínimo de capital circulante líquido. Esse capital é representado pela diferença entre ativo e passivo circulante, de acordo com a proposição de Fleuriet, Kehdy e Blanc (2003).

\subsection{POLÍTICAS DE FINANCIAMENTO}

Nos últimos anos o financiamento do capital de giro tem se tornado um assunto em evidência e muito significativo. Junto a isso, passou a ser um assunto bastante discutido na 
academia e nas empresas, devido a problemas financeiros que muitas entidades enfrentam (Machado, Machado, \& Callado, 2006).

Nesse rumo, Menéndez-Requejo (1996) cita que a capacidade de investimento da empresa depende particularmente de sua capacidade de autofinanciamento, das formas de acesso a financiamentos externos à instituição e, consequentemente, das condições obtidas para esse financiamento.

No caso das pequenas empresas, o endividamento geralmente é de curto prazo (Osteryoung, Constand, \& Nast, 1992) e as instituições bancárias, segundo Gastón e Jarne (1995), são a fonte de financiamento mais importante.

$\mathrm{Na}$ concessão de crédito os gestores bancários exigem informações referentes à contabilidade para analisar o desempenho atingido em momentos anteriores da empresa para que possam assegurar os melhores termos e condições de negociação do financiamento. Então, pelo maior risco de falência atrelado ao investimento, as pequenas empresas têm que arcar com custo de capital mais elevado, o que acarreta uma maior dificuldade para que essas empresas captem recursos de terceiros (IAPMEI/DPDPME, 1995).

Assim, Cassiolato, Britto e Vargas (2002) alegam que a falta de crédito pode ser considerada um entrave para o avanço das pequenas empresas. Apesar de existirem alguns aparatos legais e administrativo-gerenciais aptos a dar tratamento especial às micro e pequenas empresas e de alguns esforços do governo em promover uma política de apoio e fomento a essas instituições, ainda restam grandes desafios a serem superados para que esse segmento empresarial se fortaleça e assuma um papel mais relevante na economia nacional.

\subsection{ESTUDOS ANTERIORES ASSEMELHADOS}

O financiamento das operações empresariais é um tema discutido há muitos anos na literatura. Contudo, no que tange a pesquisas anteriores assemelhadas ao foco deste estudo considerou-se pertinente evidenciar os trabalhos elencados sinteticamente no Quadro 1. 
Quadro 1 - Pesquisas anteriores semelhantes (autores, objetivos e resultados)

Durand (1952): aborda a existência de uma estrutura ótima de capital, afirmando que o custo de capital de terceiros permanece estável até determinado nível de endividamento, e a partir desse nível a firma torna-se mais propensa ao risco de falência.

Modigliani \& Miller (1958): concluíram que observadas premissas como ausência de custos de falência, todas as empresas se situarem na mesma classe de risco, ausência de tributação pessoal, ausência de crescimento nos fluxos de caixa das empresas, ausência de assimetria de informação e de custos de agência, a estrutura de capital, ou seja, a forma como as empresas se financiam é irrelevante.

Jensen \& Meckling (1976): criação de uma teoria de estrutura de propriedade das companhias baseadas nos inevitáveis conflitos de interesse individuais e com predições testáveis empiricamente.

Miller (1977): reconhece que a consideração de tributos pessoais também poderia afetar o valor da empresa. A inclusão da tributação pessoal diminuiria o benefício gerado pela alavancagem no sentido de que, pagando impostos sobre seus ganhos, os credores exigiriam maiores taxas de juros, de forma a compensar a perda para o fisco, aumentando assim o custo do endividamento.

Myers (1977): esclarece que o endividamento pode originar políticas de endividamento sub ótimas, do ponto de vista da maximização do valor da empresa. Cita que o valor da empresa é uma soma entre o valor dos ativos ligados à exploração e o valor das opções reais sobre futuras oportunidades de crescimento da empresa. Mostra, também, que as empresas com boas oportunidades de crescimento devem evitar o recurso ao endividamento, na medida que com maior nível de risco, estas endividam-se mais do que aquelas que se revelam menos arriscadas.

Labini (1980): diferencia os investimentos reais dos investimentos financeiros. Para o autor, os investimentos reais são aqueles que geram aumento da capacidade produtiva, como os investimentos em instalações, máquinas e estoques. Já os investimentos financeiros são as aplicações que visam aumentar a segurança da empresa e sua capacidade de ganho, podendo até facilitar a obtenção de recursos para financiar os investimentos reais.

Myers \& Majluf (1984): buscaram apontar uma ordem das fontes de captação de recursos das firmas, onde inicialmente a opção seria de autofinanciamento, seguido pelos títulos negociáveis em seu poder e, por fim, a utilização de fontes externas que são tidas como seguras.

Titman \& Wessels (1988): mostraram que empresas que apresentam maior grau de singularidade e as empresas mais lucrativas apresentam menor propensão ao endividamento, tanto de longo quanto de curto prazo. Ainda, que as empresas menores revelaram maior propensão ao endividamento de curto prazo do que as empresas maiores.

Barclay \& Smith (1995): encontraram evidência de forte relação entre o vencimento da dívida e o tamanho da empresa. Os resultados mostraram que empresas grandes emitem uma proporção significativamente maior de dívida de longo prazo. Referida constatação "é consistente com a observação de que empresas pequenas dependem mais pesadamente de dívida bancária que, tipicamente, tem vencimento mais curto do que a dívida pública. 
Stohs \& Mauer (1996): testaram a hipótese de uma relação direta entre o prazo da dívida e o tamanho da empresa, utilizando três tipos de regressões. Embora o sinal apresentado tenha sido o esperado, os resultados não foram significativos para a regressão cross-sectional. Mas, ao considerarem os pooled and fixed effects, encontraram evidência de que empresas grandes apresentam estruturas de vencimento da dívida mais longas, enquanto as menores tendem a usar dívidas de prazos mais curtos.

Demirgüç-Kunt \& Maksimovic (1999): identificaram que empresas grandes registram as taxas mais altas de dívida de longo prazo em relação ao total do ativo e também de dívida de longo prazo em relação ao total do passivo. Evidenciam, então, que existem diferenças nos padrões de financiamento para os países em diferentes níveis de desenvolvimento e para empresas grandes e pequenas e as diferenças mais acentuadas estão no uso de contratos de dívida de longo prazo.

Perobelli \& Famá (2002): revelaram que o grau de endividamento de curto prazo é negativamente relacionado a atributos como tamanho, crescimento dos ativos e lucratividade das empresas, o que indica que empresas maiores, empresas em crescimento e empresas lucrativas são menos propensas a esse tipo de endividamento.

Ozkan (2002): dessumiu que o acesso das empresas maiores aos mercados de capitais é muito mais fácil e que as empresas pequenas acham mais difícil acessar mercados de dívida de longo prazo. Apurou resultados altamente significativos de que o vencimento da dívida está positivamente relacionado ao tamanho das empresas, o que se coaduna com a visão de que empresas grandes podem ter melhor acesso a mercados financeiros para aumentar dívida de longo prazo.

Kayo \& Famá (2004): apresentam uma diferenciação entre os níveis de endividamento e o risco das empresas tangíveis-intensivas e intangíveis-intensivas. Ao comparar o mercado brasileiro ao norte-americano concluíram que as empresas intangível-intensivas revelam menores índices de endividamento apesar de maior risco, relacionando isso à utilização mais intensiva do capital próprio, bem como por apresentarem maiores retornos.

Perobelli, Silveira, Barros \& Rocha (2005): priorizaram verificar quais são os fatores indutores do grau de endividamento das empresas de capital brasileiras considerando a qualidade da governança corporativa da companhia emissora de títulos. Os resultados obtidos indicaram que a escolha da estrutura de capital das empresas parece ser antes influenciada por atributos teóricos próprios do que por uma escolha única, sendo os atributos "crescimento", "rentabilidade", "singularidade", "volatilidade" e "qualidade da governança corporativa" os mais coerentes.

Terra \& Mateus (2005): aduzem que as oportunidades de crescimento não são variáveis significativas para a escolha entre endividamento de curto e longo prazo, enquanto liquidez e efeitos de impostos são variáveis relevantes. Ainda, que as empresas de maior liquidez tendem a escolher financiamentos de curto prazo e firmas com mais impostos a pagar escolhem os de longo prazo.

Flannery \& Rangan (2006): no âmbito dos modelos dinâmicos de trade-off desenvolveram um modelo que envolve a existência de uma estrutura ideal de capital, variável de acordo com a empresa e o período considerado, bem como um fator de ajustamento parcial da estrutura atual em direção a essa estrutura ótima. 
Correa, Basso \& Nakamura (2007): analisaram o nível de endividamento das maiores empresas brasileiras à luz da pecking order theory e da trade-off theory, testando seus determinantes. Os resultados apontaram uma relação negativa entre o nível de endividamento da empresa, o grau de tangibilidade dos ativos e a rentabilidade, bem como uma relação positiva entre risco e endividamento. Além disso, demostraram que empresas de capital estrangeiro são mais endividadas que as nacionais.

Rauh \& Sufi (2010): os resultados encontrados apontaram para usos de múltiplas fontes de endividamento por empresas com baixa qualidade de crédito, sendo este achado contrário à hipótese de que a empresa escolhe sua fonte de endividamento, optando por dívida bancária ou por meio de títulos corporativos. A dispersão da dívida por distintas fontes pode ser explicada como uma forma de reduzir os conflitos de agência entre acionistas e credores, uma vez que reduz a capacidade de monitoramento do credor.

Colla, Ippolito \& Li (2013): analisaram o efeito dos benefícios associados à utilização dos tipos de dívidas em empresas norte-americanas. Os resultados evidenciaram que $85 \%$ das empresas analisadas utilizaram predominantemente apenas um tipo de dívida para financiamento de ativos, enquanto que a diversificação e especialização das dívidas ocorreram em empresas grandes e listadas em ratings de crédito.

Diamond \& He (2014): demonstraram que a estrutura da dívida e seus vencimentos têm efeitos significativos sobre as oportunidades de investimentos e suas rentabilidades. Alegam que isso acontece porque a estrutura de dívidas e os seus prazos de vencimentos afetam os riscos de falência, o custo do capital e o acesso às linhas de créditos (públicas ou privadas).

Póvoa \& Nakamura (2015): dessumiram que a lucratividade sobre os tipos de fontes de dívidas não apresentou efeito significativo, exceto sobre o nível de endividamento de curto prazo. Identificaram também um efeito negativo significativo no que tange ao risco sobre os títulos corporativos e as captações externas e um efeito positivo sobre as dívidas subsidiadas. Por fim, a liquidez corrente não apresentou efeito negativamente significativo apenas sobre os títulos corporativos, dívidas subsidiadas e as captações externas.

Peixoto, Bicalho, Marques \& Amaral (2016): verificaram o efeito do nível de transparência sobre a estrutura da dívida e os achados reforçam que quanto mais transparente for a empresa menor será a assimetria informacional entre usuários internos e externos. Com isso, os provedores de capital tendem a estar mais dispostos a concederem crédito exigindo uma remuneração mais acessível. A maior transparência não afeta apenas na capacidade da firma em se endividar, mas também na maturidade das dívidas, na estrutura de capital e na diversificação entre dívidas de curto e longo prazo, entre outros.

Fonte: elaborado pelos autores, 2017.

Convém ressaltar também que além do financiamento por intermédio da captação de recursos junto às instituições financeiras há a possibilidade conseguir crédito comercial perante fornecedores de insumos para suprir a necessidade de capital de giro das empresas. Nesse contexto, o crédito comercial representa um arranjo contratual por meio do qual o comprador e o fornecedor combinam a postergação do pagamento do valor dos bens ou serviços adquiridos para depois da data de entrega física das mercadorias ou da prestação dos serviços (Carvalho \& Schiozer, 2015). Assim, constitui-se de importante fator de impacto nas decisões de financiamentos e investimentos das empresas, independentemente do porte. Nesse rumo, a

REMIPE- Revista de Micro e Pequenas Empresas e Empreendedorismo da Fatec Osasco V. 3, N², jul.-dez. 2017. 
literatura sobre finanças de curto prazo discorreu sobre a oferta e demanda de crédito comercial entre empresas de grande porte em outros países (García-Teruel \& Martínez-Solano, 2010; Sheng, Bortoluzzo, \& Santos, 2013) e no Brasil (Saito \& Bandeira, 2010; Schiozer \& Brando, 2011; Carvalho \& Schiozer, 2015).

Contudo, nesse estudo foi priorizado o financiamento do capital de giro junto a terceiros, em detrimento da obtenção de crédito comercial. Isso é pertinente de vez que a parcela não coberta pela concessão de crédito por parte dos fornecedores tende a ser suprida com fontes externas, conforme os resultados deslindados nas próximas seções.

\section{PROCEDIMENTOS METODOLÓGICOS}

Quanto ao desenho metodológico esta pode ser caracterizada como uma pesquisa quantitativa de descrição. Rauen (2015, p. 157) menciona que esse tipo de estudo é mais conhecido como de "levantamento de dados, de sondagem ou survey e consiste na solicitação de informações a um grupo estatisticamente significativo de pessoas para posterior análise quantitativa, recorrendo-se a técnicas de pesquisa de campo". Nessa direção, Andrade (2002) pugna que os estudos descritivos se preocupam em observar os fatos, registrá-los, analisá-los, classificá-los e interpretá-los, sem a interferência direta do pesquisador no contexto.

Por outro lado, Carvalho e Schiozer (2015, p. 215) ressalvam que as pesquisas do tipo survey estão sujeitas a limitações que podem advir da existência de potenciais vieses de "não respondentes", de "aquiescência", de "straight-line" e de "respostas socialmente desejáveis". Sobre isso, Gil (2010) cita como uma das possíveis limitações desse tipo de estudo a ênfase em aspectos perceptivos, visto que levantamentos recolhem dados que se referem às percepções das pessoas acerca de si mesmas. Isto pode gerar distorções porque há muita divergência entre o que as pessoas fazem (ou sentem) e o que elas dizem a respeito.

No que tange à forma de abordagem quantitativa, Richardson (1999) aduz que essa modalidade envolve as pesquisas que empregam a quantificação, tanto nas modalidades de coleta de informações, quanto no tratamento dessas por meio de técnicas estatísticas, desde as mais simples (como percentual, média, desvio-padrão etc.) até aquelas mais complexas (como coeficientes de correlação, análises de regressão etc).

Quanto ao procedimento de coleta de dados, este aconteceu por intermédio da aplicação de questionário específico nos meses de abril a junho de 2016. Esse questionário inicialmente foi testado em um grupo de cinco possíveis respondentes, que posteriormente não participaram do estudo final, para ajustar as questões incluídas. Referidos questionários foram 
preenchidos a partir das informações coligidas por um grupo de alunos de curso de Administração de universidade sediada na área geográfica abrangida, devidamente treinados para essa atividade.

A amostra utilizada envolveu 299 (duzentos e noventa e nove) pequenas empresas da microrregião da Associação dos Municípios da Região de Laguna - Amurel (sul de Santa Catarina), cujos gestores concordaram em participar. Portanto, caracteriza-se por amostra de caráter intencional, associada à possibilidade de acesso aos dados desse conjunto de entidades por parte dos pesquisadores.

\section{ANÁLISE E INTERPRETAÇÃO DOS DADOS}

As próximas seções discorrem sobre as peculiaridades das empresas abrangidas no estudo e, posteriormente, evidenciam os principais aspectos da realidade apurada acerca da captação de recursos para o capital de giro.

\subsection{CARACTERÍSTICAS DAS EMPRESAS PESQUISADAS}

As companhias estudadas estão concentradas na microrregião da AMUREL, localizada na mesorregião "Sul de Santa Catarina", que compreende os municípios de Armazém, Braço do Norte, Capivari de Baixo, Garopaba, Grão-Pará, Gravatal, Imaruí, Imbituba, Jaguaruna, Laguna, Orleans, Pedras Grandes, Pescaria Brava, Rio Fortuna, Sangão, Santa Rosa de Lima, São Ludgero, São Martinho, Treze de Maio e Tubarão.

No que tange às principais características das empresas pesquisadas, cabe evidenciar os seguintes aspectos:

a) Ramo de atividade: do total de 299 empresas, 134 destas (44,82\%) atuam como “comércio", 67 empresas (22,41\%) são indústrias e 98 entidades $(32,78 \%)$ são prestadoras de serviços.

b) Cargo dos respondentes: 172 eram donos/sócios (57,53\%), 95 eram gerentes $(31,77 \%)$ e os demais se dividiam entre auxiliares administrativos e contadores.

c) Tempo de existência: 14 empresas $(4,68 \%)$ tinham menos de um ano, 43 entidades (14,38\%) existiam entre 1 e 3 anos, 111 companhias (37,12\%) existem entre 4 e 10 anos, enquanto que outras 131 empresas $(43,81 \%)$ atuam há mais de 10 anos.

d) Número de funcionários: entre 1 e 10 funcionários era o número de colaboradores de 149 empresas (49,83\%), 43 empresas (14,38\%) possuíam entre 11 e 20 empregados, 42 empresas (14,05\%) empregavam entre 21 e 50 funcionários, 33 
empresas $(11,04 \%)$ utilizavam quadro entre 51 e 100 empregados e 32 empresas $(10,70 \%)$ tinham somente o proprietário trabalhando nas atividades operacionais.

e) Configuração jurídica: 172 empresas são "sociedades por quotas de responsabilidade limitada" (LTDA.), o que equivale a 57,53\% da amostra. Ainda, 70 entidades (23,41\% são registradas como "Micro Empreendedor Individual” (M. E. I.), 44 empresas (14,72\%) como "Empresa Individual de Responsabilidade Limitada" (EIRELI), dez entidades são constituídas como "Micro Empresa" (M. E.) e três respostas selecionaram a opção “Outras” (0,99\%).

\subsection{CARACTERÍSTICAS DA CAPTAÇÃO DE RECURSOS PARA CAPITAL DE GIRO}

Nas próximas seções são evidenciadas as informações oriundas dos questionários aplicados, priorizando-se os aspectos relacionados com fontes de captação, taxas de juros, prazo médio dos contratos, nível de prioridade dado às fontes de recursos e às contas a liquidar, renegociação de dívidas e motivos alegados para evitar empréstimos bancários.

\subsection{FONTES DE CAPTAÇÃO PRIORIZADAS}

O primeiro aspecto investigado buscou resposta para uma indagação a respeito de quantos por cento dos recursos para capital de giro foi obtido (captado), na média nos últimos 12 meses, de determinadas fontes. Acerca disso, as respostas coligidas estão sintetizadas na Tabela 1. 
Tabela 1 - Fontes de captação do capital de giro utilizadas

\begin{tabular}{|c|c|c|c|c|c|}
\hline Itens & $\begin{array}{l}\text { Não houve } \\
\text { este tipo de } \\
\text { captação }\end{array}$ & $\begin{array}{r}\text { Entre } \\
1 \%-10 \% \\
\end{array}$ & $\begin{array}{r}\text { Entre } \\
11 \%-20 \% \\
\end{array}$ & $\begin{array}{r}\text { Entre } \\
21 \%-50 \% \\
\end{array}$ & $\begin{array}{r}\text { Mais } \\
\text { de } 50 \% \\
\end{array}$ \\
\hline Sócios & 99 & 58 & 36 & 43 & 63 \\
\hline Empréstimos banc. & 160 & 52 & 54 & 30 & 3 \\
\hline Desc. Tít. Bancos & 182 & 68 & 25 & 19 & 5 \\
\hline Desc. Tít. Coop. Créd. & 230 & 41 & 19 & 7 & 2 \\
\hline Desc. Tít. Factoring & 240 & 35 & 13 & 5 & 6 \\
\hline Lim. Cheque Esp. & 204 & 58 & 20 & 11 & 6 \\
\hline Créd. Rotativo & 202 & 46 & 33 & 11 & 7 \\
\hline $\mathrm{CDC}$ & 237 & 38 & 16 & 6 & 2 \\
\hline Vendor & 263 & 12 & 18 & 6 & - \\
\hline Agiotas & 265 & 18 & 10 & 6 & - \\
\hline Venda de Imobilizado & 217 & 52 & 18 & 7 & 5 \\
\hline
\end{tabular}

Fonte: dados da pesquisa, 2017.

Os resultados expressos na Tabela 1 evidenciam que a fonte de capital de giro mais utilizada pelas empresas participantes do estudo foram os sócios do empreendimento, totalizando 200 empresas das 299 pesquisadas. Isso pode indicar que os sócios confiam no retorno do seu investimento em decorrência do sucesso da empresa e que existe um esforço para que a firma não tenha que suportar as taxas de juros do mercado financeiro.

Ainda, os dados citados apontam também um alto índice de empresas que se utilizam de empréstimos bancários (139 das 299 pesquisadas) para obter recursos para o capital de giro.

A terceira opção mais priorizada refere-se ao desconto de títulos em bancos, visto que 182 empresas afirmaram não fazer esse procedimento, o que implica que 117 companhias $(39,13 \%$ do total) recorrem a essa modalidade de captação.

No caso das demais opções apresentadas nesta questão as respostas mostraram que a preferência dos pesquisados foi a seguinte (em ordem decrescente): crédito rotativo, limite do cheque especial, venda de imobilizado, desconto de títulos em cooperativa de crédito, crédito direto ao consumidor, desconto de títulos em factoring's, vendor e agiotas.

\subsubsection{Taxas de juros}

A segunda questão desta parte versava sobre as taxas de juros (em percentual ao mês) que foram contratadas nas captações de recursos para o capital de giro das empresas pesquisadas. No que concerne a esse aspecto a Tabela 2 descortina a situação encontrada no contexto das 299 empresas abrangidas pelo estudo. 
Tabela 2 - Taxas de juros contratadas para captação de capital de giro (\% ao mês)

\begin{tabular}{|c|c|c|c|c|c|c|c|}
\hline & & $1 \% \mathrm{a}$ & & & & $+\mathrm{de}$ & \\
\hline Itens & Até $2 \%$ & $3 \%$ & $3,1 \%$ a $4 \%$ & $4,1 \%$ a $5 \%$ & $5,1 \%$ a $10 \%$ & $10 \%$ & Não houve \\
\hline Empréstimos Banc. & 91 & 62 & 32 & 13 & 4 & 2 & 95 \\
\hline Desc. Tít. Bancos & 111 & 46 & 28 & 9 & 1 & 1 & 103 \\
\hline $\begin{array}{l}\text { Desc. Tít. } \\
\text { Coop.Créd. }\end{array}$ & 132 & 31 & & 0 & 3 & 1 & 116 \\
\hline Desc. Tít. Factoring & 127 & 33 & 15 & 5 & 3 & - & 116 \\
\hline $\begin{array}{l}\text { Créd. Rotativo } \\
\text { Créd. Direto ao }\end{array}$ & 111 & 41 & 15 & 9 & 4 & 3 & 116 \\
\hline Cons. & 143 & 22 & 8 & 6 & 2 & - & 118 \\
\hline Vendor & 150 & 17 & 6 & 4 & 4 & 1 & 117 \\
\hline Agiotas & 150 & 17 & 9 & 6 & 2 & - & 115 \\
\hline
\end{tabular}

Fonte: dados da pesquisa, 2017.

O conjunto de respostas obtidas nesse quesito permite aceitar que a maioria das empresas visa obter a contratação das taxas de juros mais atrativas no mercado. Esse aspecto é corroborado pelo fato de trabalharem com taxas de juros na faixa de "até $2 \%$ " ao mês, independente da fonte de financiamento. Por outro lado, constata-se que contingente bem menor de companhias se submeteu às operações de crédito com taxas de juros superiores a 5\% a mês.

Das alternativas apresentadas no questionário aplicado, os empréstimos bancários foram a opção mais comum, visto que apenas 95 das empresas pesquisadas $(31,77 \%)$ relataram não ter realizado esse tipo de operação. No que tange às taxas de juros, nessa modalidade de captação a maioria das companhias pesquisadas (198 ou 66,22\% do total) obteve recursos mediante remuneração mensal igual ou inferior a 5\% ao mês, enquanto que apenas 6 respondentes afirmaram ter obtido recursos com taxa superior a esse patamar.

A segunda opção mais utilizada foi o desconto de títulos em bancos, que apresentou números assemelhados ao que foi relatado no parágrafo precedente.

As demais operações (desconto de títulos em cooperativas de crédito e em factoring's, crédito rotativo, crédito direto ao consumidor - $\mathrm{CDC}$, vendor e agiotas) tiveram desempenho parecido, visto que em torno de $39 \%$ dos respondentes anotaram não terem utilizado tais fontes e cerca de $60 \%$ captou recursos nestas origens com taxas mensais de até $5 \%$. 


\subsubsection{Prazos médios das contratações de empréstimos bancários}

$\mathrm{Na}$ sequência do estudo foram levantados dados sobre o prazo médio de pagamento dos empréstimos bancários contratados para obtenção de recursos para capital de giro, sendo que a situação encontrada está expressa de modo detalhado na Tabela 3.

Tabela 3 - Prazo médio dos empréstimos bancários para capital de giro

\begin{tabular}{lrr}
\hline Itens & Frequência & $\%$ do total \\
\hline Não contratou & 150 & $50,17 \%$ \\
Menor que 3 meses & 8 & $2,68 \%$ \\
Entre 3-6 meses & 17 & $5,69 \%$ \\
Entre 6-12 meses & 36 & $12,04 \%$ \\
Entre 12-24 meses & 51 & $17,06 \%$ \\
Entre 24-60 meses & 37 & $12,37 \%$ \\
Total & 299 & $100,00 \%$ \\
\hline
\end{tabular}

Fonte: dados da pesquisa, 2017.

Pelos percentuais mencionados na Tabela 3 constatou-se que entre as empresas que contrataram empréstimos para capital de giro o prazo mais utilizado para pagamento das obrigações situou-se na faixa entre 12 e 24 meses, sendo este o informado por 51 empresas (17,06\% do total). Ainda, foram apurados números muito aproximados na utilização dos prazos de pagamento de 6 e 12 meses (36 empresas ou 12,04\%), ao passo que 37 respondentes indicaram a utilização de recursos com prazo de pagamento entre 24 e 60 meses (equivalente a $12,37 \%$ dos participantes). No que concerne às demais empresas que contrataram esse tipo de operação bancária com prazo igual ou inferior a seis meses, estas totalizaram 25 respostas (8,37\% das entidades pesquisadas).

Contudo, o resultado mais relevante se refere ao fato de que 150 respondentes $(50,17 \%)$ salientaram que não foram contratados empréstimos bancários para suprir a necessidade de capital de giro das operações das companhias pesquisadas. Esse tipo de procedimento denota certa aversão a esta modalidade de captação de recursos, cujos motivos alegados para tal atitude são comentados em seção posterior.

\subsubsection{Percentual captado por tipo de fonte bancária}

O quarto ponto inquirido discorria acerca do percentual dos valores monetários obtidos nas captações de recursos para capital de giro em instituições bancárias nos últimos 12 meses, cujo cenário deslindado está resumido na Tabela 4. 
Tabela 4 - Percentual dos valores captados para capital de giro em instituições bancárias

\begin{tabular}{lrrrrrr}
\hline Itens & $\begin{array}{r}\text { Não } \\
\text { houve }\end{array}$ & Entre 1\%-5\% & Entre 6\%-10\% & Entre 11\%-25\% & Entre 26\%-50\% & $\begin{array}{r}\text { Mais } \\
50 \%\end{array}$ \\
\hline Bancos Comerc. & 149 & 43 & 29 & 20 & 27 & 31 \\
Coop. de Crédito & 232 & 33 & 8 & 14 & 6 & 6 \\
BNDES & 250 & 19 & 15 & 4 & 8 & 3 \\
BRDE & 292 & 3 & 2 & 2 & - & - \\
BADESC & 292 & 3 & 2 & 1 & - & 1 \\
Outros & 273 & 17 & 1 & 6 & - & 2 \\
\hline
\end{tabular}

Fonte: dados da pesquisa, 2017.

A partir das respostas apresentadas na Tabela 4 é possível verificar que naquelas que fizeram esse tipo de captação existe uma concentração maior nos bancos comerciais, em detrimento de cooperativas de crédito e bancos de fomento (BNDES, BRDE \& BADESC).

Destarte, os dados coletados revelam que os bancos comerciais foram as instituições mais acionadas para a captação de recursos com a finalidade de utilização no capital de giro das participantes do estudo, de vez que 31 empresas financiaram mais de 50\% do seu capital de giro nesse tipo de instituição. Na mesma direção, entre as empresas que optaram por essa fonte verificou-se também que 43 delas captaram entre 1 e 5\% do total; 29 entidades financiaram entre 6 e 10\%; 20 companhias responderam ter captado entre 11 e $25 \%$ e cerca de 27 organizações informaram ter captado entre 26 e $50 \%$ nos bancos comerciais.

No caso das cooperativas de crédito, estas também se destacaram por serem utilizadas como fontes para obtenção desse tipo de recurso, visto que 67 das 299 empresas afirmaram fazer uso dessas entidades. Acerca disso, 33 empresas fizeram captações que representaram participação percentual entre 1 e $5 \%$ do total; oito instituições utilizaram cooperativas de crédito para financiar entre 6 e 10\% de suas captações de recursos para giro; 14 empresas recorreram a essa fonte para financiar de 11 a $25 \%$ de suas necessidades; seis participantes do estudo financiaram de 26 a $50 \%$ e outras seis captaram mais de $50 \%$ dos recursos para capital de giro em cooperativas de crédito.

Contudo, foi percebida uma baixa utilização dos bancos de desenvolvimento, visto que apenas 49 (ou 16,39\%) das 299 companhias abrangidas afirmaram ter contratado esse tipo de captação junto ao BNDES, enquanto que sete respondentes $(2,34 \%)$ citaram que recorreram ao BRDE e outras sete utilizaram recursos do BADESC. Esse baixo índice de empresas que 
tiveram acesso a esses bancos de fomento pode ser considerado uma característica negativa das empresas de pequeno porte da região geográfica em tela.

\subsubsection{Nível de prioridade na escolha da fonte de captação de recursos}

A quinta questão buscou conhecer qual a fonte de captação de recursos para capital de giro deveria ser priorizada no entendimento dos respondentes. Sobre esse aspecto, as respostas coligidas estão sintetizadas na Tabela 5.

Tabela 5 - Prioridade para captação de recursos para capital de giro

\begin{tabular}{lrrrrr}
\hline Itens & $\begin{array}{r}\text { Absoluta } \\
\text { prioridade }\end{array}$ & $\begin{array}{r}\text { Alta } \\
\text { prioridade }\end{array}$ & $\begin{array}{c}\text { Média } \\
\text { prioridade }\end{array}$ & $\begin{array}{c}\text { Baixa } \\
\text { prioridade }\end{array}$ & $\begin{array}{r}\text { Nenhuma } \\
\text { prioridade }\end{array}$ \\
\hline Sócios & 60 & 62 & 69 & 67 & 41 \\
Desc. Títulos em Bancos & 10 & 30 & 66 & 126 & 67 \\
Desc. Títulos Coop. Créd. & 3 & 9 & 39 & 200 & 48 \\
Lim. de Cheque Especial & 2 & 6 & 25 & 208 & 58 \\
Crédito Rotativo & 4 & 21 & 52 & 148 & 74 \\
Empréstimos Bancários & 13 & 36 & 61 & 112 & 77 \\
Venda de Imobilizados & 11 & 35 & 48 & 132 & 73 \\
\hline Fonte: dados da pesquin
\end{tabular}

Fonte: dados da pesquisa, 2017.

O conjunto de respostas obtidas nesse quesito mostra que o foco prioritário para obter mais recursos para o capital de giro está centrado nos sócios. Nesse rumo, apenas 108 das 299 participantes atribuíram "baixa prioridade" (67 empresas) ou "nenhuma prioridade" (41 empresas) para essa opção. Por outro lado, as opções de "absoluta prioridade", "alta prioridade" e "média prioridade" foram as escolhidas, respectivamente, por 60 empresas (20,07\%), 62 organizações $(20,74 \%)$ e 69 entidades $(23,08 \%)$. Contudo, vale ressaltar que, a priori, a aplicação de dinheiro na empresa por parte dos sócios deveria ser considerada "integralização de capital", em vez de uma forma de empréstimo.

Das opções apresentadas havia ainda outra que não implicava a contratação de operações bancárias, ou seja, a venda de imobilizados. Neste caso, 94 empresas (31,44\% respondentes) alegaram que esta alternativa teria prioridade "absoluta", "alta" ou "média"; enquanto que 205 entidades atribuíram "prioridade baixa" ou "nenhuma prioridade" para se desfazer de ativos com o intuito de obter recursos para capital de giro. 
Pelo ângulo das opções relativas às linhas de crédito bancário se constatou que as formas de captação de recursos que apresentam as maiores taxas de juros são também aquelas que as empresas menos consideraram prioritárias, como a utilização do limite do cheque especial, do crédito rotativo e do desconto de títulos em bancos e cooperativas.

Nessa direção, foram atribuídas as classificações de "baixa" e "nenhuma" prioridade por $88,96 \%$ dos respondentes $(208+58)$ para o uso do limite de cheque especial, enquanto que $82,94 \%$ das respostas $(200+48)$ qualificaram assim o desconto de recebíveis em cooperativas de crédito e $74,25 \%$ das empresas $(148+74)$ adjetivaram desta forma para a utilização do crédito rotativo. Além disso, números assemelhados foram apurados para as modalidades de desconto de títulos em bancos e empréstimos bancários: aproximadamente $64 \%$ das companhias enfocadas consideraram como pouco interessante essas formas de captação.

\subsubsection{Prioridade para pagamento de contas com saldo insuficiente de caixa}

No prosseguimento da pesquisa se desejou conhecer qual a prioridade atribuída pelos respondentes para determinados procedimentos nas ocasiões em que havia saldo insuficiente no caixa para quitar as dívidas existentes. Nesse rumo, os dados apurados estão expressos de forma bem resumida na Tabela 6 .

Tabela 6 - Prioridade perante saldo insuficiente de caixa

\begin{tabular}{lrrrrr}
\hline Itens & Absoluta & Alta & Média & Baixa & Nenhuma \\
\hline Não pagar tributos & 17 & 24 & 45 & 66 & 147 \\
Pedir mais prazo a fornecedores & 107 & 90 & 48 & 37 & 17 \\
Atrasar dívidas bancárias & 13 & 19 & 32 & 76 & 159 \\
Atrasar folha de pagamentos & 26 & 18 & 20 & 45 & 190 \\
Vender imobilizado & 67 & 44 & 66 & 48 & 74 \\
\hline
\end{tabular}

Fonte: dados da pesquisa, 2017.

Constatou-se que a medida prioritária para os gestores das empresas pesquisadas seria negociar o aumento do prazo de pagamento junto aos fornecedores. Nesse rumo, 107 participantes afirmaram atribuir prioridade absoluta para esse procedimento, 90 empresas expressaram dar prioridade alta, 40 empresas colocaram como prioridade média, 37 como prioridade baixa e apenas 17 não cogitaram utilizar essa solução para sanar ou minimizar a insuficiência de caixa para quitar dívidas.

Na segunda colocação ficou a venda de imobilizado, visto que 111 das 299 empresas afirmaram qualificar como prioridade absoluta (67) ou alta (44) essa iniciativa. Mas, em sentido REMIPE- Revista de Micro e Pequenas Empresas e Empreendedorismo da Fatec Osasco 
oposto, $78,60 \%$ dos respondentes consideraram que atrasar dívidas bancárias e atrasar o pagamento de salários seriam medidas com baixa ou nenhuma prioridade no contexto atual. Ainda, $71,24 \%$ das entidades pesquisadas aduziram que não pagar tributos também seria uma opção pouco interessante ou não prioritária $(66+147$ respondentes $)$.

\subsubsection{Renegociações de dívidas}

Outro aspecto averiguado no estudo diz respeito à possibilidade de terem ocorrido renegociações de dívidas bancárias nos últimos cinco anos, cujas respostas colhidas foram consolidadas na Tabela 7.

Tabela 7 - Número de renegociações de dívidas bancárias nos últimos cinco anos

\begin{tabular}{lrr}
\hline Itens & Frequência & $\%$ do total \\
\hline Não ocorreram renegociações de dívidas bancárias & 220 & 73,57 \\
Para renovar linhas de crédito & 34 & 11,37 \\
Para liquidar dívida antecipadamente & 14 & 4,68 \\
Para reduzir taxas de juros & 31 & 10,37 \\
Total & 299 & 100,00 \\
\hline
\end{tabular}

Fonte: dados da pesquisa, 2017.

Os dados coletados na pesquisa mostram que a grande maioria das empresas não efetuou renegociação de dívidas, pois 220 destas fizeram tal afirmação (o que equivale a $73,57 \%$ das participantes do estudo). Entretanto, no caso das outras 79 empresas que informaram ter renegociado dívidas bancárias nos últimos cinco anos, as duas principais motivações relacionam-se com a renovação das linhas de crédito $(11,37 \%)$ e com a tentativa de reduzir as taxas de juros contratadas (10,37\%). Ainda, foi mencionada por 14 companhias a razão de liquidar dívidas antecipadamente, o que representou apenas 4,68\% das respostas colhidas.

\subsubsection{Proporção da captação de crédito bancário perante o faturamento}

$\mathrm{Na}$ sequência da pesquisa foi indagado sobre o percentual do faturamento tomado como crédito bancário (para "Giro" e "Investimentos") na média dos últimos cinco anos. No que tange a esse aspecto as respostas dos participantes revelaram a situação exposta na Tabela 8. 
Tabela 8 - Percentual de captação bancária (giro e investimento) sobre o faturamento

\begin{tabular}{lrrrr}
\hline & \multicolumn{3}{c}{ Capital de giro } & \multicolumn{3}{c}{ Investimentos } \\
Itens & No. Empresas & $\%$ do total & No. Empresas & $\%$ do total \\
\hline Não usou crédito bancário & 126 & $42,14 \%$ & 110 & $36,79 \%$ \\
$1 \%$ a 5\% do faturamento anual & 49 & $16,39 \%$ & 72 & $24,08 \%$ \\
$6 \%$ a 10\% do faturamento anual & 46 & $15,38 \%$ & 48 & $16,05 \%$ \\
$11 \%$ a 25\% do faturamento anual & 45 & $15,05 \%$ & 44 & $14,72 \%$ \\
$26 \%$ a 50\% do faturamento anual & 24 & $8,03 \%$ & 19 & $6,35 \%$ \\
Mais de 50\% do faturamento anual & 9 & $3,01 \%$ & 6 & $2,01 \%$ \\
\hline
\end{tabular}

Fonte: dados da pesquisa, 2017.

Pelos dados da Tabela 8 se percebe uma baixa utilização de recursos externos para capital de giro ou para investimentos, em termos de percentuais sobre o faturamento. Das 299 entidades participantes do estudo, $126(42,14 \%)$ citaram não ter contratado financiamento para capital de giro e $110(36,79 \%)$ não usaram crédito bancário para financiar seus investimentos.

Contudo, no que tange àquelas que fizeram uso desses recursos é possível identificar que $49(16,39 \%)$ empresas utilizaram de 1 a $5 \%$ de seu faturamento anual com financiamento de capital de giro e $72(24,08 \%)$ com investimentos.

Ao analisar os demais dados restou evidente que apenas uma pequena parte das entidades participantes adota uma política de utilização de crédito bancário que assume proporção mais elevada em relação ao faturamento anual. Nesse sentido, somente $38,46 \%$ das empresas responderam que captaram recursos para capital de giro cujos valores equivalem entre $6 \%$ e $50 \%$ do faturamento anual ( $46+45+24$ empresas); enquanto que $37,12 \%$ das empresas $(48+44+19)$ informaram o mesmo nível percentual de comprometimento das vendas no que se refere à captação de recursos para investimentos.

Outro aspecto que chama a atenção é que nove empresas afirmaram ter feito captação bancária para aplicação no capital de giro em montante superior a 50\% do faturamento e seis relataram algo semelhante em relação aos recursos para investimentos. Ou seja, comprometeram parcela expressiva das vendas com tais operações bancárias.

\subsubsection{Razões para evitar a contratação de crédito bancário}

O último questionamento da presente pesquisa buscou conhecer o nível da importância atribuída pelos respondentes a determinados motivos que podem ser aventados para evitar a contratação de empréstimos e financiamentos bancários. Nesse sentido, a Tabela 9 contém uma síntese das respostas coletadas.

REMIPE- Revista de Micro e Pequenas Empresas e Empreendedorismo da Fatec Osasco V. 3, N², jul.-dez. 2017. 
Tabela 9 - Importância atribuída aos motivos para evitar empréstimos e financiamentos bancários

\begin{tabular}{|c|c|c|c|c|c|}
\hline Itens & $\begin{array}{r}\text { Extremamente } \\
\text { importante }\end{array}$ & $\begin{array}{r}\text { Muito } \\
\text { importante }\end{array}$ & Importante & $\begin{array}{r}\text { Pouco } \\
\text { importante }\end{array}$ & Irrelevante \\
\hline $\begin{array}{l}\text { Altas Taxas de Juros } \\
\text { Burocracia ou Documentação }\end{array}$ & 143 & 68 & 56 & 16 & 16 \\
\hline Exigida & 25 & 30 & 77 & 87 & 80 \\
\hline $\begin{array}{l}\text { Instabilidade Econômica do País } \\
\text { Incerteza sobre o Futuro da }\end{array}$ & 63 & 84 & 89 & 43 & 20 \\
\hline Empresa & 48 & 51 & 82 & 63 & 55 \\
\hline Influência da Opinião de Terceiros & 8 & 11 & 32 & 82 & 166 \\
\hline Não Ter Conhecimento Suficiente & 33 & 38 & 53 & 66 & 109 \\
\hline Outras Razões & 8 & & 29 & 30 & 224 \\
\hline
\end{tabular}

Fonte: dados da pesquisa, 2017.

Com base nos dados apresentados na Tabela 9 é possível afirmar que os fatores que mais inibem a contratação de empréstimos e financiamentos bancários no âmbito das empresas pesquisadas são, por ordem decrescente:

1) Altas taxas de juros: esta razão foi apontada como relevante por 267 empresas $(89,30 \%)$, de vez que 143 destas a consideraram "extremamente importante", enquanto que 68 registraram ser "muito importante" e 56 selecionaram a opção “importante". Portanto, somente 32 empresas $(10,70 \%)$ citaram que este seria um motivo com pouca ou nenhuma relevância.

2) Instabilidade econômica do país: este argumento foi apontado por 236 participantes $(78,93 \%)$ como um fator importante para desmotivar o empresário a contratar empréstimos e financiamentos nos bancos. Por outro lado, 63 empresas (21,07\% do total de participantes) mencionaram que isso teria baixa ou nenhuma importância nas decisões a respeito.

3) Incerteza sobre o futuro da empresa: este foi o terceiro maior motivo apontado pela pesquisa, visto que 181 respondentes (60,54\%) atribuíram-lhe importância acentuada $(48+51+82$ empresas classificaram como "extremamente importante", "muito importante" ou "importante", respectivamente). No sentido oposto, quase $40 \%$ dos questionados (118) consideraram esse aspecto como tendo mínima ou pouca influência nessas possibilidades de negociações de crédito. 
4) Burocracia ou documentação requerida: essa razão foi indicada como relevante por 132 empresas (44,15\% do total), visto que 25 respondentes consideraram ser "extremamente relevante", 30 opinaram que era "muito importante" e 77 disseram que seria "importante". Contudo, contingente superior de respondentes $(55,85 \%$ do total) escolheram as opções "pouco importante" e "irrelevante".

5) Não ter conhecimento suficiente: esse motivo foi adjetivado como relevante por 124 empresas $(41,47 \%)$, mas um número maior de respondentes (175) afirmou que o mesmo não seria importante (58,53\% das respostas).

É válido salientar, ainda, que a "influência da opinião de terceiros" e "outras razões" foram apontadas por mais de $82 \%$ dos participantes como tendo baixa ou nenhuma relevância nesse tipo de decisão.

\subsection{RESULTADOS DO ESTUDO}

As seções precedentes evidenciaram as principais características da captação de recursos nas empresas da microrregião da Amurel, cujos principais "achados" são abordados na sequência.

Os resultados do estudo apontam que a fonte de recursos para capital de giro (Tabela 1) que teve a preferência entre as possibilidades investigadas foi a dos sócios da empresa, o que pode indicar uma confiança na rentabilidade do empreendimento e/ou uma tentativa no sentido de evitar as taxas de juros do mercado financeiro. Verificou-se, ainda, que muitas dessas pequenas empresas utilizam o empréstimo bancário e o desconto de títulos em bancos, totalizando 39,13\% deste contingente abrangido no estudo. A prioridade da utilização dos sócios como fonte de dinheiro para o cotidiano dessas entidades se coaduna com a Pecking Order Theory (ou Teoria do Equilíbrio das Fontes) proposta por Myers (1984), onde se admite o pressuposto que há assimetria informacional entre gestores e investidores. Nessa direção, Kayo e Famá (2004) mostram que as empresas mais lucrativas se endividam menos porque preferem financiar seus investimentos com os recursos internos. Se esses recursos não forem suficientes para financiar todos os projetos de investimento, as empresas contraem dívidas.

No que concerne às informações sobre as taxas de juros (Tabela 2), dessumiu-se que as pequenas empresas em tela tentam evitar se expor às remunerações cobradas pelo mercado financeiro para disponibilizar capital de giro. Sobre isso, as respostas coligidas apontaram que quando existe a necessidade de captação de recursos em instituições financeiras a prioridade é 
sempre pelas taxas mais atrativas, visto que a grande maioria dos respondentes asseverou que trabalhava com juros de até $2 \%$ ao mês. Além disso, entre as opções de captação contratadas mediante pagamento de juros, os empréstimos bancários foram os mais utilizados (por 204 empresas), no que foram seguidos pelas operações de desconto de títulos em bancos (com 196 respostas neste sentido). As demais fontes de recursos tiveram níveis assemelhados: agiotas (184 empresas), crédito rotativo (183), desconto de títulos em cooperativas de crédito (183), desconto de títulos em factoring's (183), vendor (182) e crédito direto ao consumidor (181).

Ao analisar o resultado referente aos prazos médios de pagamentos das contratações de empréstimos bancários (Tabela 3) se concluiu que os mais utilizados foram aqueles da faixa entre 12 e 24 meses (opção de 51 empresas), enquanto que a segunda posição coube às operações com prazos na faixa entre 24 a 60 meses (utilizado por 37 empresas). Além disso, 36 companhias informaram que contrataram empréstimos com prazo entre 6 e 12 meses; outras 17 entidades preferiram prazos entre 3 e 6 meses e somente oito gestores citaram que fizeram uso desta fonte de recursos por prazo menor que três meses. Por outro lado, as respostas obtidas mostram um contexto no qual das 299 empresas pesquisadas, apenas 149 (49,83\%) destas fizeram uso de empréstimos bancários, trazendo indícios de que tentam evitar a contratação de tal modalidade de operação financeira para suprir as necessidades de capital de giro. Parte desse problema pode estar ligado à afirmação de Brito, Corrar e Batistella (2007) de que o mercado brasileiro possui custo de capital de terceiros não somente em função do risco de o tomador não cumprir suas obrigações, mas inclusive sobre a fonte do financiamento. Em razão dessas determinantes algumas linhas de crédito de longo prazo são direcionadas a investimentos específicos e têm custo financeiro inferior às linhas de curto prazo, pois o risco para o credor acaba se tornando menor.

Quanto aos percentuais dos valores monetários captados em instituições bancárias (Tabela 4), observou-se que há uma preferência maior pelos bancos comerciais em detrimento das cooperativas de crédito e bancos de fomento (como BNDES, BRDE etc.). A respeito disso, as informações repassadas pelos participantes do estudo dão conta de que 150 empresas utilizaram os bancos comerciais para captar recursos, enquanto que 67 participantes negociaram com cooperativas de crédito e apenas 63 gestores citaram ter captado recursos em agências de fomento. Destarte, cabe salientar a baixa procura por essas agências que visam fomentar a atividade econômica, visto que são bancos com o objetivo principal de financiar capital fixo e de giro para empreendimentos previstos em programas de desenvolvimento, na unidade da Federação onde estiverem sediados (Banco Central do Brasil, 2017).

REMIPE- Revista de Micro e Pequenas Empresas e Empreendedorismo da Fatec Osasco V. 3, N², jul.-dez. 2017. 
Sobre esse contexto é possível cogitar de que o nível de prioridade na escolha da fonte de captação evidencia uma preferência maior para o procedimento de obter recursos junto aos sócios, de vez que após isso é que aparecem, em ordem decrescente, as opções por empréstimos bancários, venda de imobilizados, desconto de títulos em bancos, crédito rotativo, desconto de títulos em cooperativas de crédito e limite do cheque especial. Com isso, se conclui que as pequenas empresas pesquisadas tendem a evitar a exposição a taxas de juros mais elevadas. Essa peculiaridade é corroborada indiretamente quando são analisadas as respostas acerca da priorização do pagamento de contas quando ocorrem situações de saldo insuficiente em caixa (Tabela 6). Nesse caso, a solução preferida é pedir mais prazo de pagamento aos fornecedores, seguida de vender imobilizado, atrasar a folha de pagamentos, não pagar tributos e por último atrasar dívidas bancárias. Assim, pode-se deduzir que há grande preocupação desses pequenos empreendimentos com a questão de juros e multas cobrados pelos bancos, pois classificaram como última opção atrasar as dívidas bancárias, colocando à frente desta as alternativas de atrasar folha de pagamento e postergar o pagamento de tributos, por exemplo.

No âmbito da questão relacionada com a renegociação de dívidas nos últimos cinco anos (Tabela 7) o resultado mostrou que 73,57\% das pequenas empresas participantes do estudo não efetuaram renegociações de dívidas nesse lapso temporal. Portanto, somente 79 entidades fizeram algum tipo de renovação de débito: 34 companhias disseram ter feito isso para renovar linhas de crédito, 31 entidades renegociaram para reduzir a taxa de juros e 14 optaram por liquidar antecipadamente suas dívidas. As oscilações de taxas de juros, especialmente entre 2012 e 2014, foi uma oportunidade que poderia ter sido melhor aproveitada por esses empresários. Nesse rumo, a portabilidade das dívidas, instituída por meio da Resolução 3.401/2006 do Banco Central do Brasil poderia ser um instrumento adequado para obter melhores condições de financiamento perante os bancos brasileiros.

Outro "achado" relevante discorre sobre as principais razões consideradas pelos gestores dessas pequenas empresas para não contratarem empréstimos e financiamentos bancários (Tabela 9). Muito à frente das demais alegações situou-se o motivo das "altas taxas de juros", visto que somente 32 respondentes aduziram ser pouco importante ou irrelevante esse fator. Em seguida apareceram as razões "instabilidade econômica do país" (onde 63 participantes afirmaram não ter relevância esse aspecto) e "incerteza sobre o futuro da empresa" (com 118 respostas no sentido de ser irrelevante ou pouco importante). A grande influência da motivação relacionada com as taxas de juros se coaduna com os resultados comentados nos 
parágrafos precedentes, especialmente com a intenção de evitar a tomada de empréstimos nos bancos comerciais.

Entretanto, é coerente mencionar que na análise do diagnóstico deslindado neste estudo devem ser levadas em conta também as dinâmicas culturais das empresas pesquisadas, conforme defendido por Brito, Corrar e Batistella (2007). Referidos autores asseveram que as teorias mais sofisticadas referentes à estruturação do capital foram desenvolvidas em contextos diferentes dos observados no Brasil. Por isso, quando se avaliar um possível enquadramento destas no cenário nacional deveriam ser consideradas as peculiaridades existentes em determinadas regiões, segmentos mercadológicos, portes empresariais etc. Nessa direção, tomados em conjunto os resultados deste estudo permitem concluir que há dificuldades com a utilização do crédito bancário como forma de alavancar as atividades do grupo de pequenas empresas visado.

\section{CONCLUSÕES}

Este estudo pretendeu obter respostas para questão relacionada às características da captação de recursos para capital de giro de pequenos empreendimentos da microrregião da Amurel, no sul catarinense. Para tanto, teve o objetivo de identificar as peculiaridades relacionadas a essa modalidade captação na área geográfica citada, no que tange às pequenas empresas. Nesse rumo, os autores entendem que tal pergunta foi adequadamente respondida e o objetivo foi atingido, conforme relatado nas seções precedentes.

Quanto aos resultados mais relevantes é interessante destacar alguns aspectos. O primeiro é que a maioria das companhias pesquisadas tem evitado a contratação de operações bancárias para não se submeter às taxas de juros praticadas pelo mercado financeiro nacional. Em virtude disso se constatou que há preferência por utilizar recursos dos sócios em detrimentos de financiamentos bancários atrelados a algum custo financeiro. No que concerne às taxas de juros que as empresas estão dispostas a pagar, restou comprovado que existe um esforço pela busca de taxas mais atrativas, onde a grande maioria das organizações optou por realizar operações de crédito com taxas de até $2 \%$ ao mês, independentemente da fonte de financiamento utilizada. Quanto aos prazos médios da contratação de empréstimos, foram priorizadas linhas de crédito com a possibilidade de pagamento entre 12 e 24 meses, mostrando que essas empresas evitaram os contratos com prazos mais exíguos.

O segundo ponto relevante versa acerca das empresas que se sujeitaram ao pagamento dos juros cobrados pelo mercado financeiro, onde sobressaiu-se a maior utilização dos bancos REMIPE- Revista de Micro e Pequenas Empresas e Empreendedorismo da Fatec Osasco 
comerciais, que superaram as agências de fomento e as cooperativas de crédito como fonte principal para obtenção de recursos para capital de giro. Essa peculiaridade pode ser qualificada como um ponto negativo, visto que as fontes desprezadas costumam ofertar linhas de crédito mais acessíveis e por prazos mais extensos.

Além disso, quando foram analisadas as fontes de captação de recursos priorizadas pelas organizações estudadas percebeu-se que há uma concentração maior na figura dos sócios, reforçando a ideia da existência de uma linha de raciocínio na direção de evitar os juros bancários. Os respondentes informaram também que quando há insuficiência de numerários no caixa a primeira iniciativa é no sentido de renegociar prazos com fornecedores, deixando a possibilidade de atrasar dívidas bancárias como última opção. Ainda, se constatou que grande contingente das empresas em tela $(73,57 \%)$ não efetuou a renegociação de suas dívidas nos últimos cinco anos, enquanto que entre aquelas que tomaram essa iniciativa os focos foram a renovação de linhas de crédito e a redução das taxas de juros contratadas.

O último aspecto relevante está ligado às motivações que levam os gestores desses pequenos empreendimentos a evitar a contratação de captações bancárias para giro, onde se apurou que as razões maiores estavam atreladas às altas taxas de juros (principalmente), à instabilidade econômica do Brasil e à incerteza sobre o futuro do negócio.

A principal contribuição teórica do estudo reside no fato de ter propiciado um diagnóstico sobre as formas de captação de recursos para capital de giro no contexto de pequenas empresas. Mesmo que restrito à determinada microrregião do país, considera-se que pode servir para que entidades de apoio às pequenas empresas, universidades regionais e instituições de crédito ou de fomento conheçam melhor a realidade desses empreendimentos acerca do tema abordado. Com isso, iniciativas (como consultorias, treinamentos, palestras sobre captação de recursos etc.) com o fito de melhorar a gestão financeira desse porte empresarial podem ser estudadas (ou aprimoradas) para ajudar no fortalecimento desse importante segmento econômico.

No que tange às limitações do estudo, cabe destacar que a amostra utilizada ficou circunscrita às pequenas empresas sediadas na microrregião da Amurel (Sul de Santa Catarina). Portanto, os resultados oriundos devem ser considerados como representativos somente desta microrregião, o que não permite extrapolar para outras realidades ou contextos assemelhados. Adicionalmente, por utilizar um questionário como instrumento de coleta de dados, as respostas que fundamentaram as conclusões podem conter algum tipo de viés (conforme mencionado na seção 3) que deve ser levado em conta na análise a respeito.

REMIPE- Revista de Micro e Pequenas Empresas e Empreendedorismo da Fatec Osasco 
Como recomendações para trabalhos futuros sugere-se replicar a pesquisa em outras regiões do país no sentido de comparar os resultados, bem como abranger empresas maiores, visando conhecer se há diferenças significativas nos dois contextos de portes empresariais

\section{REFERÊNCIAS}

Andrade, M. M. de (2002). Como preparar trabalhos para cursos de pós-graduação: noções práticas (5a ed.). São Paulo, SP: Atlas.

Assaf Neto, A., \& Lima, F. G. (2010). Fundamentos de administração financeira. São Paulo, SP: Atlas.

Audretsch, D. B., \& Beckmann, I. A. M. (2007). From small business to entrepreneurship policy. In D. B. Audretsch, I. Grilo \& A. R. Thurik (Orgs.). Handbook of research on entrepreneurship policy (pp.36-53). Cheltenham, Inglaterra: Edward Elgar.

Banco Central do Brasil. (2006). Resolução no 3.401/2006. Recuperado de www.bcb.gov.br/pre/normativos/

Banco Central do Brasil (2017). Sistema Financeiro Nacional. 2017. Recuperado de http://www.bcb.gov.br/pre/composicao/agencia_fomento.asp

Barclay, M., \& Smith, C. (1995). The Maturity Structure of Corporate Debt. The Journal of Finance, 50(2), 609-631. doi:10.2307/2329421

Belt, B. (1979). Working capital policy and liquidity in the small business. Journal of Small Business Management, 17(3), 43-71.

Braga, R. (1991). Análise avançada do capital de giro. Caderno de Estudos Fipecafi, 1(3), 1 20.

Brito, G. A. S., Corrar, L. J., \& Batistella, F. D. (2007). Fatores determinantes da estrutura de capital das maiores empresas que atuam no Brasil. Revista Contabilidade \& Finanças - USP, 18(43), 9-19.

Canongia, D. S. (2014). Como as empresas brasileiras de capital aberto escolhem sua estrutura de capital? (Dissertação de Mestrado, Faculdade de Economia, Programa de Pós-graduação em Economia Aplicada, Universidade Federal de Juiz de Fora). Recuperado de https://repositorio.ufjf.br/jspui/bitstream/ufjf/717/1/diogosennacanongia.pdf

Carvalho, C. E., \& Abramovay, R. (2004). O difícil e custoso acesso ao sistema financeiro. In C. A. dos Santos (Org.). Sistema financeiro e as micro e pequenas empresas: diagnósticos e perspectivas (pp.17-45). Brasília, DF: Sebrae.

Carvalho, C. J., \& Schiozer, R. F. (2015). Determinantes da oferta e da demanda de créditos comerciais por micro, pequenas e médias Empresas. Revista Contabilidade \& Finanças - USP, 26(68), 208-222. Doi: 10.1590/1808-057x201500940 
Cassiolato, J. E., Britto, J., \& Vargas, M. (2002). Formatos organizacionais para financiamento de arranjos e sistemas de MPME. In: Interagir para competir: promoção de arranjos produtivos e inovativos no Brasil (pp.249-285). Brasília, DF: Sebrae/Finep.

Colla, P., Ippolito, F., \& Li, K. (2013). Debt structure and debt specialization. The Journal of Finance, 68(5), 2117-2141.

Correa, C. A., Basso, L. F. C., \& Nakamura, W. T. (2013). A estrutura de capital das maiores empresas brasileiras: análise empírica das teorias de Pecking Order e trade-off, usando panel data. RAM. Revista de Administração Mackenzie, 14(4), 106-133. https://dx.doi.org/10.1590/S1678-69712013000400005

Costa, L. G. T. A., Costa, L. R. T. A., \& Alvim, M. A. (2011). Valuation: manual de avaliação e reestruturação econômica de empresas (2a ed.). São Paulo, SP: Atlas.

Damodaran, A. (2002). Finanças corporativas aplicadas: manual do usuário. Porto Alegre, RS: Bookman.

Demirgüc-Kunt, A., \& Maksimovic, V. (1999). Institutions, financial markets, and firm debt maturity. Journal of Financial Economics, 54(3), 295-336.

Diamond, D. W., \& He, Z. (2014). A theory of debt maturity: the long and short of debt overhang. The Journal of Finance, 69(2), 719-762.

Dorabelia, M. M. (1995). Mensuração e simulação das necessidades de capital de giro e dos fluxos financeiros operacionais: um modelo de informação contábil para a gestão financeira. (Dissertação de Mestrado em Controladoria e Contabilidade). Universidade de São Paulo. São Paulo.

Durand, D. (1952). Costs of debt and equity funds for business: trends and problems of measurement. National Bureau of Economic Research, 194(5), 216-262.

Flannery, M. J., \& Rangan, K. P. (2006). Partial adjustment toward target capital structures. Journal of Financial Economics, 79(3), 469-506.

Fleuriet, M, Kehdy, R., \& Blanc, G. (2003). O modelo Fleuriet: a dinâmica financeira das empresas brasileiras (5a ed.). Rio de Janeiro, RJ: Elsevier.

García-Teruel, P. J., \& Martínez-Solano, P. (2010). Determinants of trade credit: a comparative study of European SMEs. International Small Business Journal, 28(3), 215-233. Doi: $10.1177 / 0266242609360603$

Gastón, S. C. \&, Jarne, J. I. J. (1995). La Información financiera en el contexto internacional: análisis descriptivo. Revista Española de Financiación y Contabilidad, 24(85), 937-968.

Gil, A. C. (2010). Métodos e técnicas de pesquisa social. São Paulo, SP: Atlas.

Gitman, L. J. (1997). Princípios de administração financeira (9a ed.). São Paulo, SP: Harbra. 
IAPMEI/DPDPME. (1995). O financiamento como factor chave de sucesso para o desenvolvimento empresarial, Pequena e Média Empresa. Instituto de Apoio às Pequenas e Médias Empresas e ao Investimento, 7(3).

Jensen, M. C., \& Meckling, W. H. (1976). Theory of the firm: managerial behavior, agency costs and ownership structure. Journal of Financial Economics, 3(4), 305-360.

Kayo, E. K., \& Famá, R. (2004). A estrutura de capital e o risco das empresas tangívelintensivas e intangível-intensivas. Revista de Administração, 39(2), 164-176.

Labini, P. S. (1980). Oligopólio e progresso técnico. Rio de Janeiro, RJ: Forense Universitária/EDUSP.

Lima, G. T., \& Meirelles, A. J. A. (2005). Regimes de financiamento, risco de endividamento e fragilidade financeira. Estudos Econômicos (São Paulo), 35 (2), 317-334. Doi: $10.1590 /$ S0101-41612005000200004

Machado, M. A. V., Machado, M. R., \& Callado, A. L. C. (2006). Análise dinâmica e o financiamento das necessidades de capital de giro das pequenas e médias empresas localizadas em cidade de João Pessoa, PB: um estudo exploratório. Base - Revista de Administração e Contabilidade da Unisinos, 3(2), 139-149.

Menéndez-Requejo, S. (1996). Interdependencia de las decisiones financieras en las empresas españolas. Revista Española de Financiación y Contabilidad, 25(87), 315-342.

Miller, M. (1977). Debt and Taxes. The Journal of Finance, 32(2), 261-275. doi:10.2307/2326758

Modigliani, F., \& Miller, M. (1963). Corporate Income Taxes and the Cost of Capital: A Correction. The American Economic Review, 53(3), 433-443. Retrieved from http://www.jstor.org/stable/1809167

Modigliani, F., \& Miller, M. (1958). The Cost of Capital, Corporation Finance and the Theory of Investment. The American Economic Review, 48(3), 261-297. Retrieved from http://www.jstor.org/stable/1809766

Myers, S. C. (1984). The Capital Structure Puzzle. The Journal of Finance, 39(3), 575-592. doi: $10.2307 / 2327916$

Myers, S. C. (1977). Determinants of corporate borrowing. Journal of Financial Economics, 5(2), 147-175. Doi: 10.1016/0304-405X(77)90015-0

Myers, S. C., \& Majluf, N. S. (1984). Corporate financing and investment decisions when firms have information that investors do not have. Journal of Financial Economics, 13(2), 187-221. Doi: $10.1016 / 0304-405 X(84) 90023-0$

Nakamura, W. T., Jucá, M. N., \& Bastos, D. D. (2011). Estrutura de maturidade das dívidas das empresas brasileiras: um estudo empírico. Revista de Administração Contemporânea, 15(2), 228-248. 
Osteryoung, J., Constand, R. L., \& Nast, D. (1992). Financial ratios in large public and small private firms. Journal of Small Business Management, 30(3), 35-46.

Perobelli, F. F. C., \& Famá, R. (2003). Fatores determinantes da estrutura de capital para empresas latino-americanas. Revista de Administração Contemporânea, 7(1), 9-35.

Póvoa, A. C. S., \& Nakamura, W. (2015). Relevância da estrutura de dívida para os determinantes da estrutura de capital: um estudo com dados em painel. Revista Contemporânea de Contabilidade, 12(25), 03-26. doi: http://dx.doi.org/10.5007/2175-8069.2015v12n25p03

Rauen, F. J. (2015). Roteiros de iniciação científica: os primeiros passos da pesquisa científica desde a concepção até a produção e a apresentação. Palhoça, SC: Unisul.

Rauh, J. D., \& Sufi, A. (2010). Capital structure and debt structure. Review of Financial Studies, 23(12), 4242-4280. doi: 10.1093/rfs/hhq095

Richardson, R. J. (1999). Pesquisa social: métodos e técnicas. São Paulo, SP: Atlas.

Rochman, R. R. (2007). Capital de giro. GV Executivo, 6(3), 30.

Saito, R., \& Bandeira, M. L. (2010). Evidência empírica de usos de crédito comercial de empresas brasileiras de capital aberto. Revista Brasileira de Administração, 7 (3), 242-259.

Sanvicente, A. Z. (2010). Administração financeira (3a ed.). São Paulo, SP: Atlas.

Schiozer, R. F., \& Brando, J. A. P. (2011). A oferta de Trade Credit pelas empresas brasileiras de capital aberto. Revista Brasileira de Finanças, 9(4), 585-612.

Sebrae (2004). Fatores condicionantes e taxa de mortalidade de empresas no Brasil. Relatório de pesquisa. Disponível em: goo.gl/tHhm5hcontent_copy

Sebrae (2013). Sobrevivência das empresas no Brasil, coleção estudos e pesquisas. Recuperado de

https://www.sebrae.com.br/Sebrae/Portal\%20Sebrae/Anexos/Sobrevivencia_das_empresas_n o_Brasil=2013.pdf

Sheng, H. H., Bortoluzzo, A. B., \& Santos, G. A. P. (2013). Impacto do crédito comercial sobre o investimento de inventário firme durante as crises financeiras: evidências da América Latina. Emerging Markets Finance \& Trade, 49(4), 32-52.

Stohs, M., \& Mauer, D. (1996). The determinants of corporate debt maturity structure. The Journal of Business, 69(3), 279-312. Retrieved from http://www.jstor.org/stable/2353370

Titman, S., \& Wessels, R. (1988). The determinants of capital structure choice. The Journal of Finance, 43(1), 1-19.

Van Stel, A., Carree, M., \& Thurik, R. The effect of entrepreneurial activity on national economic growth. Small Business Economics, 24(3), 311-321. Doi: doi:10.1007/s11187-005$1996-6$ 
Vogel, J., \& Wood Jr., T. (2012). Práticas gerenciais de pequenas empresas industriais do Estado de São Paulo: um estudo exploratório. Revista de Empreendedorismo e Gestão de Pequenas Empresas, 1(2), 117-140. 